\title{
KALA PENGEMBANGAN MASYARAKAT MENJADI PENGEMBANGAN BISNIS : CREATING SHARED VALUE ANTARA ANTAM DENGAN PERAJIN DAN PEDAGANG PERHIASAN EMAS DAN PERAK DI BALI
}

\author{
Agustinus Toko Susetio $^{\text {I) } \text { Jalal }^{2}}$ \\ 1) Vice President Human Capital and CSR - PT Antam Tbk UPBN Maluku Utara \\ 2) Chairperson of Advisory Board - Social Investment Indonesia
}

\begin{abstract}
ABSTRAK
ANTAM adalah perusahaan pertambangan yang memiliki praktik pengelolaan sosial dan lingkungan yang telah sesuai bahkan melampaui ketentuan hukum di Indonesia dan standar internasional. Oleh karena itu, ketika terdapat kebutuhan dari para perajin dan pedagang perhiasan di Indonesia untuk bisa menembus pasar internasional yang semakin memerhatikan keberlanjutan, ANTAM ada dalam posisi sebagai mitra pemasok bahan baku yang dipersyaratkan. ANTAM bukan semata-mata melakukan penjualan kepada mereka, melainkan juga berkontribusi dalam memberikan pengetahuan, keterampilan, dan akses yang dibutuhkan para perajin dan pedagang itu. Dalam bisnis perhiasan, konsep green business dapat dilihat dengan adanya Responsible Jewelry Council (RJC) dan Fairtrade International yang merupakan organisasi international yang memiliki kepedulian dalam mempromosikan praktik industri perhiasan yang sesuai dengan seluruh aspek tanggung jawab sosial untuk mencapai keberlanjutan. Kedua organisasi tersebut adalah anggota dari ISEAL (International Social and Environmental Accreditation and Labelling). RJC memiliki $500+$ anggota yang melakukan kegiatan penambangan, pengolahan dan pemurnian, pembuatan perhiasan, sampai dengan pelaku usaha penjualan perhiasan. RJC Code of Practice mencakup di antaranya standar hak asasi manusia, hak pekerja, dampak lingkungan, publikasi atau penjelasan tentang produk dan beberapa topik lainnya yang dimutakhirkan terakhir pada tahun 2013 yang di antaranya mengacu pada UN Guiding Principles on Businesses and Human Rights yang dikeluarkan oleh PBB dan memasukkan ketentuan mengenai sumber bahan baku yang bebas konflik. Sertifikasi RJC juga membantu perusahaan dalam kemamputelusuran suatu produk, uji kelayakan rantai pasokan, dan penggunaan standar tersebut terus meningkat. Fairtrade International juga bergerak dalam bidang yang sama, namun lebih fokus pada tambang rakyat dan komunitasnya. ISEAL mendukung para penambang untuk meningkatkan hubungan jangka panjang dan adil untuk memastikan bahwa pertambangan dapat menekan angka kemiskinan dan mendukung terwujudnya pembangunan berkelanjutan. ANTAM membantu para perajin dan pedagang perhiasan untuk dapat memenuhi standar internasional itu, selain menjadi pemasok bahan bakunya. Penjualan ANTAM meningkat seiring dengan semakin banyaknya perajin dan pedagang yang bisa memenuhi standar internasional. Kasus kolaborasi antara ANTAM dengan para perajin dan pedagang perhiasan di Bali yang dipaparkan menunjukkan bahwa gagasan Porter dan Cramer (2011) tentang creating shared value (CSV) bisa dilaksanakan oleh industri pertambangan, dengan menggabungkan pengembangan masyarakat (community development) dan pengembangan bisnis (business development).
\end{abstract}

\section{ABSTRACT}

ANTAM is a mining company that has social and environmental management practices that comply with and even exceed Indonesian legal requirements as well as meet international standards. Therefore, when there is a need from crafters and jewelry traders in Indonesia to be able to penetrate the international market which is increasingly concerned about sustainability, ANTAM is in a position as a supplier of required raw materials. In the jewelry business, the concept of green business can be seen with the Responsible Jewelry Council (RJC) and Fairtrade International, which is an international organization that has a concern in promoting the practice of the jewelry 
industry in accordance with all aspects of social responsibility to achieve sustainability. Both organizations are members of ISEAL (International Social and Environmental Accreditation and Labeling). RJC has 500+ members who carry out mining, processing and refining activities, jewelry making, to business people selling jewelry. The RJC Code of Practice includes human rights standards, workers' rights, environmental impacts, publications or explanations about products and several other topics, most recently updated in 2013, among which refer to the UN Guiding Principles on Businesses and Human Rights issued by the United Nations and include provisions regarding conflict-free sources of raw materials. RJC certification also helps companies in product traceability, supply chain feasibility testing, and the use of these standards continues to increase. Fairtrade International is also engaged in the same field, but is more focused on the mining of the people and their communities. ISEAL supports miners to improve long-term and equitable relations to ensure that mining can reduce poverty and support sustainable development. ANTAM is helping crafters and jewelry traders to be able to meet these international standards, in addition to being a supplier of raw materials. ANTAM's sales have increased along with the increasing number of craftsmen and traders who can meet international standards. The case of collaboration between ANTAM and crafters and jewelers in Bali presented shows that the idea of Porter and Cramer (2011) about creating shared value (CSV) could be implemented by the mining industry, by way of combining community development and business development.

\section{A. PENDAhuluan}

Sebagaimana dikemukakan oleh penggagasnya, konsep creating shared value (CSV) adalah "policies and practices that enhance the competitiveness of a company while simultaneously advancing the economic, environmental and social conditions in the communities in which it operates" atau kebijakan dan praktik pengelolaan usaha untuk meningkatkan daya saing perusahaan sekaligus menjawab berbagai isu sosial ekonomi masyarakat di sekitar wilayah usahanya (Porter dan Kramer, 2011). Alih-alih menggunakan kekuatan finansial perusahaan untuk sekadar memberikan donasi, CSV menjadikan isu sosial sebagai jendela untuk menggali inovasi dan mengembangkan bisnisnya dengan menjawab berbagai isu yang dihadapi masyarakat. Dengan CSV, perusahaan diuntungkan tidak hanya melalui peningkatan kepercayaan dan dukungan seluruh stakeholder - atau keuntungan operasional dan reputasional — namun, lebih dari itu, perusahaan mendapatkan manfaat ekonomi atau keuntungan finansial dari program yang mereka jalankan sehingga perusahaan semakin tumbuh dan berkembang.

Ide dasar dari CSV berkembang dari ide Strategic Philantrophy, di mana perusahaan dapat menyatukan tujuan bisnis dan tujuan sosial dengan melakukan suatu program yang dapat memenuhi kebutuhan perusahaan dan kebutuhan social (Porter dan Kramer, 2002). Beberapa contoh perusahaan yang telah melaksanakan hal tersebut adalah Cisco, American Express, Exxon Mobile, DreamWorks SKG, dan Apple Computer. Selanjutnya Porter dan Kramer (2006) mengembangkan konsep yang lebih luas, yaitu Strategic CSR, yaitu CSR yang didesain sejak awal untuk mendatangkan manfaat bagi pemangku kepentingan dan perusahaan, yang membedakannya dengan Responsive CSR yang sekadar mengikuti tuntutan pemangku kepentingan tanpa jelas manfaatnya untuk perusahaan.

CSV, menurut para pakar (mis. Crane, dkk. 2014), sebetulnya bukanlah bentuk di luar CSR, sebagaimana yang diklaim oleh Porter dan Kramer. Melainkan, merupakah salah satu perwujudan CSR yang strategis itu, di antara bentuk-bentuk lain seperti strategic CSR (Werther dan Chandler, 2011), first mover advantage (Sirsly dan Lamertz, 2008), dan fortune at the bottom of pyramid (Prahalad, 2004) dan triple bottom line (Elkington, 1997). Seluruh pemikiran itu menegaskan bahwa CSR - yaitu tanggung jawab perusahaan atas dampak yang ditimbulkan oleh aktivitas dan keputusannya, dalam rangka berkontribusi pada pencapaian tujuan pembangunan berkelanjutan (ISO, 2010) - seharusnya membawa manfaat untuk perusahaan dan pemangku kepentingannya, 
bukan salah satunya saja. Perbedaan yang mendasar dari CSV adalah bahwa keuntungan yang diperoleh perusahaan harus bisa dibuktikan bersifat keuntungan finansial.

Desain dari CSV adalah gabungan dari tiga hal. Pertama adalah social needs atau kebutuhan ekonomi, sosial dan lingkungan tertentu yang dihadapi oleh masyarakat. Kedua adalah business opportunities and challenges atau peluang dan tantangan bisnis yang timbul dari kebutuhan tersebut. Dan ketiga adalah corporate assets and expertise atau aset dan keahlian yang dimiliki oleh perusahaan dan dapat dimanfaatkan untuk mewujudkan kebutuhan masyarakat itu menjadi peluang bisnis. Meringkas desain CSV dengan sangat jelas, Welford (2013) menyatakan: "Shared value initiatives are designed to: Provide a business return; (by) Address a specific social need; (through) Efficiently and effectively leverage corporate assets, and Create measurable value for business and community."

Dalam konsep CSV perusahaan dapat menciptakan nilai ekonomi dengan menciptakan nilai sosial. Sedikitnya terdapat tiga cara yang berbeda untuk melaksanakan hal tersebut yaitu reconceiving products and markets, redefining productivity in value chains, dan enabling local cluster development (Porter dan Kramer, 2011). Pada strategi pertama perusahaan fokus pada penciptaan dan distribusi produk yang memenuhi kebutuhan masyarakat yang sebelumnya tak terpenuhi. Strategi kedua menekankan pada tata cara yang meningkatkan produktivitas dan inklusivitas di sepanjang rantai nilai. Sementara, strategi ketiga menekankan pada penguatan hubungan antara kesuksesan perusahaan dengan berkembangnya bisnis di masyarakat setempat. Ketiga hal tersebut adalah bagian yang saling terkait dari shared value, sehingga dengan meningkatkan nilai dari salah satu hal tersebut, akan menciptakan peluang peningkatan bagi yang lain.

Meskipun terdapat kelemahan-kelemahan CSV sebagai sebuah konsep Strategic CSR (Crane, dkk., 2014), praktik integrasi pemecahan isu sosial ekonomi dan pencapaian keuntungan finansial perusahaan telah dilakukan oleh banyak perusahaan. Daya tarik utama CSV adalah desain yang do good do well, atau melakukan hal yang baik untuk masyarakat dan lingkungan dengan cara yang dapat menguntungkan perusahaan. Kalau hal ini memang bisa dilakukan di seluruh sektor industri, maka akan lebih banyak lagi perusahaan yang akan mendatangkan dampak positif bagi pemangku kepentingannya. Daya tarik tersebut telah membuat banyak peneliti bisnis mengelaborasi konsep tersebut untuk berbagai konteks (Michelini, 2012; Ragas dan Culp, 2014; Baines, 2015; Wieland (ed.), 2017).

Di sisi praktik, berbagai jenis industri telah menerapkan konsep CSV ini sebagai sarana untuk memadukan pelaksanaan CSR dengan kebutuhan pengembangan usaha. Pertanyaannya adalah apakah CSV ini juga dapat diterapkan untuk industri ekstraktif seperti industri pertambangan (Albanese, 2014) mengingat pada awalnya CSV dibangun melalui penelitian saksama di industri FMCGs.

Penelitian ini mencoba menjawab pertanyaan tersebut dengan melihat Program Pemberdayaan Perajin Perak di Celuk Bali yang dikembangkan oleh PT ANTAM Tbk (selanjutnya disebut ANTAM), di mana melalui program tersebut ANTAM mengedukasi para perajin untuk menggunakan bahan baku yang berkualitas dan jelas legalitasnya sehingga hasil kerajinan mereka juga akan terjamin kualitas dan legalitasnya. Dengan meningkatnya jaminan kualitas dan legalitas ini dapat meningkatan kepercayaan pasar sehingga penjualan mereka juga meningkat. Semakin banyak perajin yang sadar untuk selalu menggunakan bahan baku emas dan perak yang terjamin kualitas dan legalitasnya, maka ANTAM sebagai produsen emas dan perak juga akan mendapatkan keuntungan dengan meningkatnya penjualan bahan baku emas dan perak. 


\section{B. METODOLOGI PENELITIAN}

Penelitian ini merupakan hasil kombinasi studi pustaka, serta pengamatan melalui survey dan wawancara, kepada para pengelola kegiatan CSR ANTAM dan para perajin dalam Program Pemberdayaan Perajin Perak di Celuk Bali, di mana Program tersebut dilakukan melalui kerja sama ANTAM dengan Ditjen PEN Kementerian Perdagangan RI pada Tahun 2018.

\section{HASIL DAN PEMBAHASAN}

Sejak dahulu emas memiliki nilai yang tinggi, dan banyak digunakan untuk membuat berbagai barang guna memenuhi kebutuhan manusia, mulai dari perhiasan, perkakas, dan alat tukar. Emas juga menjadi simbol kesejahteraan seseorang dan bahkan simbol kemakmuran masyarakat. Karena nilai dan manfaatnya, emas banyak dicari sampai ke dalam perut bumi. Sampai saat ini emas masih menjadi barang yang bernilai tinggi, dan bahkan cadangan devisa negara disimpan dalam bentuk emas.

Selain emas, perak juga menjadi salah satu barang yang nilainya cukup tinggi dan dikategorikan sebagai logam mulia meskipun tidak dihargai setinggi emas. Ketersediaan perak di alam lebih melimpah dibandingkan emas dan sering ditemukan bersama-sama mineral lain seperti emas, tembaga, timah, dan seng. Dalam banyak sistem moneter pramodern perak juga digunakan sebagai alat tukar. Selain sebagai alat tukar, perak banyak digunakan sebagai perhiasan dan ornament, peralatan makan, panel surya, penyaringan air, dan banyak barang dan kebutuhan lainnya. Serupa dengan emas, saat ini perak juga digunakan sebagai alat investasi.

Cadangan emas sering ditemukan bersama-sama perak dan diperoleh dengan cara ditambang dan dimurnikan untuk dipisahkan dari bahan dan mineral lainnya. Proses penambangan, pengolahan dan pemurnian tersebut dapat menyebabkan kerusakan lingkungan dan membahayakan keselamatan serta kesehatan manusia jika tidak dilakukan dengan kaidah-kaidah yang benar. Sebagaimana kita ketahui emas dan perak yang terdapat di alam harus dipisahkan dari batuan dan tanah yang mengikatnya dengan bahan berbahaya seperti merkuri dan sianida.

Sejarah mencatat adanya bencana kemanusiaan yang sangat mengerikan akibat limbah merkuri dari pabrik di kawasan minamata yang mencemari pantai di wilayah tersebut pada tahun 1950-an. Akibat akumulasi pencemaran merkuri di laut, banyak penduduk minamata meninggal dunia akibat mengkonsumsi ikan yang sudah tercemar merkuri, dan yang selamat dari bencana tersebut mengalami kerusakan neurologi parah dan mengakibatkan kelainan pada bayi yang lahir setelahnya. Kurang lebih butuh waktu sekitar 50 tahun sebelum ikan di Minamata aman untuk dikonsumsi lagi.

Menyadari bahaya merkuri, para pelaku industri pertambangan emas mengganti merkuri dengan bahan lain yang lebih aman bagi lingkungan dan kesehatan serta keselamatan manusia. Pemerintah pun sudah melarang merkuri untuk digunakan dalam pengolahan emas. Namun sekali lagi, hal tersebut ternyata tidak membuat para penambang emas serta merta mau beralih ke bahan lainnya. Merkuri masih banyak digunakan dalam pertambangan rakyat, dan sisa bahan tersebut banyak yang terlepas ke tanah dan perairan dan terakumulasi di badan air. Penelitian kandungan merkuri di beberapa sungai yang hulunya terdapat kegiatan penambangan dan pengolahan emas menunjukkan bahwa terjadi pencemaran merkuri dimana nilai ambang batas $\mathrm{Hg}$ di dalam air sungai terlampaui akibat pencemaran dari kegiatan penambangan dan pengolahan tersebut. Bahan berbahaya merkuri dan sianida yang dilepaskan bersama-sama dengan tailing limbah dari pengolahan batuan emas menyebabkan sungai-sungai di sekitar lokasi penambangan dan pengolahan emas dan perak menjadi berbahaya bagi ekosistem sehingga air sungai menjadi tidak layak untuk dikonsumsi atau digunakan untuk memenuhi kebutuhan air bersih dan irigasi pertanian. 
Selain bahaya merkuri sebagai bahan yang banyak digunakan dalam pengolahan emas, kegiatan penambangan emas juga banyak memakan korban jiwa. Cadangan emas yang banyak terdapat di dalam perut bumi menarik para pemburu emas untuk masuk ke dalam perut bumi. Dalam pertambangan modern, underground mining (tambang bawah tanah) dilakukan dengan metode dan teknologi yang aman sehingga resiko kesehatan dan keselamatan kerja menjadi prioritas utama. Pertambangan tersebut membutuhkan investasi besar dan penguasaan teknologi sehingga hanya dapat dilakukan oleh perusahaan-perusahaan besar. Hal yang berbeda dilakukan oleh para penambang rakyat dimana mereka hanya membuat lubang-lubang kecil dan cara sederhana untuk masuk ke dalam perut bumi dan mengambil bahan batuan yang mengandung emas. Akibatnya sering terjadi kecelakaan yang berujung pada kematian para pekerja tambang.

Kegiatan penambangan rakyat tanpa ijin juga menimbulkan dampak sosial yang luar biasa. Banyak lokasi penambangan liar yang berkembang menjadi tempat-tempat yang berasosiasi dengan penyakit sosial seperti perjudian, lokalisasi, peredaran narkoba, dan lain-lain. Yang paling mendasar adalah timbulnya pola pikir instan, dimana masyarakat terdorong mengambil jalan pintas untuk memenuhi kebutuhan dan keinginannya dengan cara melakukan penambangan tanpa ijin, mengabaikan resiko keselamatan jiwa dan mengorbankan kondisi lingkungannya dengan melepaskan tailing dan bahan kimia berbahaya ke sungai yang seharusnya menjadi sumber kehidupan masyarakat.

Langkah pertama yang harus dilakukan tentunya adalah penegakan aturan hukum. Diperlukan suatu aturan yang jelas dan komitmen semua stakeholder agar kegiatan penambangan dan pengolahan emas tidak menimbulkan kerusakan lingkungan dan sosial. Sudah menjadi kebutuhan bahwa produk perhiasan harus dapat dilacak sumber bahannya dan jika diketahui bersumber dari kegiatan penambangan illegal, maka pihak berwajib dapat melakukan tindakan hukum baik kepada produsen perhiasan, penjual, maupun konsumen. Hal ini tentunya menjadi pekerjaan yang memerlukan effort yang sangat besar karena saat ini penambangan illegal masih marak terjadi di berbagai wilayah di Indonesia. Penambangan illegal ini saat ini diasosiakan dengan pertambangan rakyat.

Dari aspek regulasi, sudah ada peraturan yang mengatur mengenai penambangan rakyat, dimana masyarakat dimungkinkan untuk mendapatkan ijin pertambangan rakyat sehingga mereka dapat melakukan kegiatan penambangan yang legal. Di dalam Undang-undang N0.4 Tahun 2009 disebutkan bahwa Izin Pertambangan Rakyat, yang selanjutnya disebut IPR, adalah izin untuk melaksanakan usaha pertambangan dalam Wilayah Pertambangan Rakyat dengan luas wilayah dan investasi terbatas. Artinya IPR hanya dapat diberikan jika sebelumnya sudah ada penetapan Wilayah Pertambangan Rakyat oleh pemerintah, dimana dalam pasal 22 undang-undang tersebut dijelaskan kriteria penetapan WPR sebagai berikut:

a. Mempunyai cadangan mineral sekunder yang terdapat di sungai dan/atau di antara tepi dan tepi sungai;

b. Mempunyai cadangan primer logam atau batubara dengan kedalaman maksimal 25 (dua puluh lima) meter;

c. Endapan teras, dataran banjir, dan endapan sungai purba;

d. Luas maksimal wilayah pertambangan rakyat adalah 25 (dua puluh lima) hektare;

e. Menyebutkan jenis komoditas yang akan ditambang; dan/ atau

f. Merupakan wilayah atau tempat kegiatan tarnbang rakyat yang sudah dikerjakan sekurangkurangnya 15 (lima belas) tahun.

Selanjutnya dalam pasal 70 undang-undang tersebut dijelaskan mengenai kewajiban pemegang IPR sebagai berikut:

a. melakukan kegiatan penambangan paling larnbat 3 (tiga) bulan setelah IPR diterbitkan;

b. mematuhi peraturan perundang-undangan di bidang keselamatan dan kesehatan kerja pertambangan, pengelolaan lingkungan, dan memenuhi standar yang berlaku;

c. mengelola lingkungan hidup bersama pemerintah daerah; 
d. membayar iuran tetap dan iuran produksi; dan

e. menyampaikan laporan pelaksanaan kegiatan usaha pertambangan rakyat secara berkala kepada pemberi IPR.

Salah satu titik lemah dari regulasi yang mengatur pertambangan rakyat adalah bahwa untuk pengelolaan lingkungan, selain pemegang ijin, pemerintah daerah juga memiliki tanggung jawab dalam mengelola (Pasal 70 point c). Hal ini dinilai berpeluang melemahkan tanggung jawab pemilik ijin pertambangan karena menganggap tanggung jawab tidak hanya berada di pihak pelaksana kegiatan pertambangan. Penerjamahan ayat tersebut oleh para pembuat kebijakan di daerah akan sangat menentukan implementasinya. Di beberapa daerah bahkan ayat tersebut dijadikan dasar untuk menyerahkan tanggung jawab reklamasi sepenuhnya kepada pemerintah daerah. Hal ini berbeda dengan pengaturan mengenai Ijin Usaha Pertambangan (IUP) dimana pemegang ijin bertanggung jawab sepenuhnya dalam pelaksanakaan pengelolaan lingkungan hidup, keselamatan dan kesehatan pekerja, dan tanggung jawab sosial.

Selain dari isi regulasi, pelaksanaan pertambangan rakyat juga masih menghadapi berbagai kendala antara lain keterbatasan SDM di tingkat daerah dalam melaksanakan kewajiban pengawasan dan pembinaan, keterbatasan penguasaan pengetahuan dan teknologi oleh masyarakat yang melaksanakan kegiatan pertambangan, dan masih lemahnya praktik Good Corporate Governance di bidang pertambangan oleh para pemangku kepentingan.

Kerusakan lingkungan dan sosial akibat praktik penambangan liar dan illegal belum disadari oleh masyarakat pada umumnya, baik masyarakat yang melakukan kegiatan penambangan dan pengolahan maupun masyarakat sebagai konsumen yang menggunakan produk emas dan perak. Bahkan dapat dikatakan belum adanya kesadaran konsumen untuk menggunakan produk emas dan perak yang legal dan diproduksi dengan prinsip-prinsip keadilan lingkungan, sosial, dan praktik bisnis yang mengutamakan keberlanjutan, yang mendorong para pelaku kegiatan penambangan dan pengolahan emas dan perak tidak memperhatikan prinsip-prinsip tersebut dalam praktik usahanya. Kesadaran konsumen juga mempengaruhi perilaku produsen perhiasan emas dan perak. Sebagian besar perajin emas dan perak hanya memperhatikan aspek kualitas dan harga bahan baku yang mereka gunakan untuk memproduksi perhiasan. Kebanyakan mereka tidak peduli, darimana sumber bahan baku emas dan perak yang mereka gunakan untuk membuat perhiasan emas dan perak.

Selain konsumen, sasaran edukasi lainnya adalah para perajin perhiasan. Beberapa daerah di Indonesia dikenal sebagai daerah penghasil kerajinan perak dan emas, antara lain Bali, Yogyakarta, dan beberapa daerah lainnya di Indonesia. Pemenuhan bahan baku emas dan perak dalam industri perhiasan selama ini dipenuhi oleh para pedagang emas dan perak baik barang legal maupun illegal. Pada kenyataannya memang para perajin emas dan perak jarang sekali mempertanyakan dari mana bahan emas dan perak mereka dapatkan, karena fokus utama mereka adalah kualitas barang dan harga. Bahkan seringkali karena mahalnya harga emas dan perak, kualitas bahan tidak lagi menjadi prioritas utama. Sudah barang tentu hal ini merugikan para perajin dan juga konsumen yang akhirnya harus mendapatkan produk yang kualitasnya rendah. Akibatnya adalah kepercayaan pasar terhadap produk kerajinan emas dan perak akan menurun sehingga dapat menurunkan penjualan dan tingkat pendapatan para perajin.

Menurut penuturan para perajin di Bali, selama ini harga bahan baku perhiasan terutama perak di Bali sering dikendalikan oleh para "mafia" atau pedagang besar sehingga mereka sering tidak dapat memenuhi kecukupan bahan baku untuk pembuatan perhiasan. Kalaupun bahan baku tersedia, seringkali harganya tidak sesuai dengan harga pasar. Akibatnya mereka tidak bisa mendapatkan keuntungan yang optimal dan bahkan harus merugi demi tetap menjaga kepercayaan pelanggan.

Produk Logam Mulia berupa emas dan perak yang diproduksi oleh ANTAM, salah satu BUMN Pertambangan yang menjalankan bisnis emas dan perak, sebenarnya memiliki keunggulan 
dibandingkan produk emas dan perak lainnya yang beredar di pasar. Saat ini yang paling sering diketahui oleh masyarakat sehingga menjadi brand image adalah keunggulan produk LM ANTAM dari segi kualitasnya yang terjamin. Tidak banyak masyarakat dan konsumen yang mengetahui keunggulan lain dari produk LM ANTAM, yaitu aspek legalitas produk dan proses pembuatannya yang ramah lingkungan dan memberikan nilai tambah bagi masyarakat dan negara. Dua keunggulan inilah yang digali dan dieksplorasi lebih jauh untuk kemudian dijadikan sebagai brand image guna meningkatkan penjualan dan kepercayaan konsumen terhadap produk LM ANTAM.

Butik Emas LM di Jalan Teuku Umar No.7 Denpasar-Bali sejak Tahun 2015 sebelumnya tidak begitu dikenal oleh para perajin emas dan perak di Bali. Meskipun sebagian besar perajin tahu bahwa produk bahan baku emas dan perak dari ANTAM terjamin kualitasnya, mereka enggan membeli karena harganya yang tinggi dan juga sebagian tidak tahu bahwa mereka dapat membeli bahan baku tersebut langsung di butik emas LM di Denpasar Bali. Kelemahan dari produk LM dibandingkan produk bahan emas dan perak illegal yang beredar adalah dari aspek harga. Para perajin umumnya menggunakan bahan emas dan perak dari sumber yang tidak jelas legalitasnya karena produk tersebut ditawarkan dengan harga yang lebih rendah. Kemungkinan besar barang tersebut dapat dijual lebih murah karena memang total biaya produksinya lebih rendah, selain aspek kualitas juga menjadi penyebab barang tersebut menjadi lebih murah harganya. Ditambah lagi pajak penjualan sebesar $10 \%$ yang tidak dikenakan kepada para perajin apabila mereka membeli dari pasar gelap (black market). Sebagai perbandingan, untuk produk bahan perak yang biasanya digunakan oleh perajin perak, selisih harganya bisa mencapai sekitar $15 \%$ dari harga total. Contohnya jika harga perak LM Rp.8200 per gram (belum termasuk PPN $10 \%$ ), maka harga bahan perak yang biasa dibeli oleh perajin dari pasaran adalah Rp.7200.

Pada umumnya perajin perhiasan emas dan perak memiliki pengetahuan dan pemahaman yang terbatas mengenai proses penambangan, pengolahan dan pemurnian emas dan perak. Untuk meningkatkan pengetahuan dan pemahaman tersebut diperlukan pendekatan sesuai dengan latar belakang pengetahuan dan karakter umum masyarakatnya. Contohnya, untuk para perajin perhiasan emas dan perak di Bali kita dapat menggunakan pemahaman mengenai penghargaan orang Bali terhadap lingkungan dan penghormatan mereka terhadap budaya yang mereka miliki agar mereka tertarik untuk menggunakan bahan baku emas dan perak yang legal dan ramah lingkungan.

Edukasi dilakukan dengan menyampaikan bahwa proses penambangan dan pengolahan emas dan perak seharusnya dilakukan atas dasar keadilan sosial dan lingkungan, dengan menerapkan praktik terbaik, mengutamakan keselamatan dan kesehatan pekerja, menghormati hak-hak asasi manusia, selalu memperhatikan kelestarian lingkungan, mematuhi semua regulasi pemerintah, serta bertanggung jawab terhadap dampak sosial dan lingkungan yang diakibatkan oleh seluruh tahapan proses penambangan dan pengolahannya. Jika tidak dilakukan dengan cara-cara tersebut, keseimbangan alam akan rusak dan manusia yang akan terkena dampaknya. Dengan pendekatan tersebut, para perajin tergugah untuk lebih memahami bagaimana bahan baku yang digunakan oleh mereka untuk menghasilkan produk perhiasan.

Satu hal yang menjadi pertanyaan penting dari para perajin adalah, apakah konsumen produk perhiasan juga peduli terhadap issue tersebut. Menurut mereka para pelanggan produk perhiasan perak tidak pernah bertanya mengenai asal usul perhiasan yang akan mereka beli. Konsumen perhiasan perak umumnya hanya peduli terhadap kualitas fisik dari produk yang akan mereka beli. Ini lah mengapa edukasi kepada konsumen juga sangat penting untuk dilakukan sebagaimana telah dijelaskan sebelumnya.

Secara umum beberapa riset sebenarnya membuktikan bahwa kesadaran konsumen terhadap produk yang mereka gunakan terkait asal usul dan dampak yang ditimbulkan dari proses produksi dan penggunaan barang tersebut semakin meningkat. Meningkatnya kesadaran konsumen ini juga dapat dilihat dari semakin banyaknya perusahaan yang berlomba-lomba menciptakan image tentang produk yang mereka hasilkan adalah produk yang ramah lingkungan, diproses dengan 
metode yang ramah lingkungan, dan berusaha menampilkan perusahaan mereka sebagai perusahaan yang memiliki kepedulian terhadap masyarakat dan kelestarian lingkungan hidup.

Kesadaran konsumen untuk menggunakan produk ramah lingkungan dijelaskan oleh Hennigs, dkk (2013). Di situ dijelaskan bahwa keberlanjutan telah menjadi salah satu bagian dalam penilaian mengenai kemewahan suatu produk. Suatu produk dapat dikategorikan sebagai barang mewah jika memenuhi syarat sebagai produk yang ramah lingkungan dan peduli pada keberlanjutan. Katharine Hamnett, seorang desainer Ethical Fashion, juga menegaskan bahwa konsumen semakin meningkat perhatiannya terhadap isu lingkungan dan sosial, dan ini adalah pergeseran budaya terbesar pada abad ke-21 dan pelaku industri barang-barang mewah harus menyadari ini jika mereka ingin bertahan.

Sebagaimana yang dirumuskan oleh Elkington (1997) dalam konsep Triple Bottom Line, keberlanjutan suatu bisnis adalah lingkungan (planet), masyarakat (people) dan laba perusahaan (profit). Bahkan saat ini dengan semakin meningkatnya kesadaran bahwa lingkungan menjadi faktor terpenting dan terutama dari pilar tersebut, faktor lingkungan ditempatkan sebagai aspek yang menentukan kesejahteraan masyarakat dan profit serta keberlanjutan bisnis perusahaan. Keberlanjutan fungsi lingkungan akan sangat menentukan profitibilitas bisnis yang berkelanjutan dan pencapaian kesejahteraan dan keadilan sosial masyarakat yang berkelanjutan, sehingga pada akhirnya semua akan kembali pada kontinuitas dan pertumbuhan ekonomi korporasi.

Perubahan terus terjadi dan para pelaku pebisnis dan korporasi global sudah melangkah lebih jauh dalam menerapkan bisnis berkelanjutan dalam keputusan dan tindakan bisnis dengan motif yang beragam. Motif pertama adalah untuk menebus kesalahan sehingga ke depan akan dilihat lebih baik dan didukung secara sosial oleh pemangku kepentingan. Motif berikutnya adalah kepatuhan terhadap regulasi, menurunkan resiko bisnis, meningkatkan akses terhadap pemegang kebijakan, investor, membuka peluang akses kredit, dan memperluas bisnis perusahaan, serta meningkatkan citra perusahaan sehingga mendapatkan penilaian yang baik dari pemangku kepentingan. Semua motif tersebut akan berujung pada peroleh keuntungan bagi perusahaan.

Dalam bisnis perhiasan, konsep keberlanjutan bisnis dapat dilihat dengan adanya Responsible Jewelry Council (RJC) dan Fairtrade International yang merupakan organisasi international yang memiliki concern dalam mempromosikan praktik industry jewelry yang sesuai dengan etika dan moral, memenuhi hak asasi manusia, serta menjalankan tanggung jawab sosial dan lingkungan untuk memastikan bahwa semua tahapan dalam pembuatan jewelry mulai dari penambangan sampai dengan penjualan ke konsumen dilaksanakan sesuai standar. Kedua organisasi tersebut adalah anggota dari ISEAL (International Social and Environmental Accreditation and Labelling).

ISEAL sendiri adalah organisasi yang bertujuan untuk meningkatkan penerapan standar keberlanjutan yang keanggotaannya terbuka bagi seluruh lembaga akreditasi dan standard keberlanjutan untuk mendorong setiap pemangku kepentingan terkait menerapkan praktik-praktik pembangunan yang berkelanjutan, termasuk dalam menjalankan usaha pertambangan dan industri hilirnya.

RJC memiliki lebih dari 500 anggota perusahaan yang bergerak di industri terkait perhiasan, mulai dari perusahaan yang melakukan kegiatan penambangan, pengolahan dan pemurnian, pembuatan perhiasan, sampai dengan pelaku usaha penjualan perhiasan. RJC Code of Practice mencakup standar hak asasi manusia, hak pekerja, dampak lingkungan, publikasi atau penjelasan tentang produk dan beberapa topik lainnya yang dimutakhirkan terakhir pada tahun 2013 mengacu pada Guiding Principles on Businesses and Human Rights yang dikeluarkan oleh PBB dan memasukan ketentuan mengenai sumber bahan baku yang berasal dari sekitar daerah konflik. Sertifikasi RJC juga membantu perusahaan dalam kemamputelusuran suatu produk, uji kelayakan rantai pasokan, dan penggunaan standar tersebut terus meningkat di negara-negara yang sedang berkembang ekonominya seperti India. 
Fairtrade International juga bergerak dalam bidang yang sama, namun lebih fokus pada tambang rakyat dan komunitasnya. Emas adalah komoditas baru yang digarap oleh sertifikasi fairtrade international, dan ISEAL mendukung para penambang untuk meningkatkan hubungan jangka panjang dan menerima kesepakatan yang adil untuk memastikan bahwa pertambangan dapat menekan angka kemiskinan dan mendukung terwujudnya pembangunan berkelanjutan.

Ditjen PEN Kementerian Perdagangan Republik Indonesia menggandeng ANTAM untuk melakukan pembinaan kepada para perajin untuk meningkatkan kapasitas para perajin perak, meningkatkan kualitas produk kerajinan perak sehingga dapat meningkatkan kepercayaan pasar dan meningkatkan espor kerajinan perak. Kerja sama tersebut ditandai dengan Penandatanganan Nota Kesepahaman oleh Dirjen PEN Kementerian Perdagangan RI dengan Direktur Utama ANTAM pada Tanggal 1 Februari 2018. Melalui kerja sama tersebut para perajin semakin menyadari bahwa mereka harus menggunakan bahan baku yang terjamin kualitas dan legalitasnya ditandai dengan meningkatnya penjualan perak oleh ANTAM, di mana pada tahun 2018 ANTAM berhasil meningkatkan penjualan peraknya sebesar $11,183 \mathrm{~kg}$ dari tahun sebelumnya hanya sebesar $950 \mathrm{~kg}$.

Kerja sama yang telah dikembangkan oleh ANTAM melalui program CSR-nya dan Kementerian Perdagangan untuk meningkatkan Ekspor kerajinan perak di Celuk Bali, telah berhasil membina para perajin perak di sana sehingga mereka semakin sadar untuk menggunakan bahan baku perak yang legal dan bertanggung jawab. Hal ini dibuktikan dengan peningkatan penjualan perak di bali oleh antam pada Tahun 2018 sebesar 11,183 kg, di mana pada Tahun 2016 dan Tahun 2017 penjuaan perak di Bali hanya kurang dari $1000 \mathrm{~kg}$.

Keberhasilan tersebut membuktikan bahwa program CSR tidak hanya berperan sebagai pelaksanaan tanggung jawab sosialnya kepada pemangku kepentingan, melainkan menjadi instrumen bagi perusahaan, pemerintah dan masyarakat dalam mengembangkan bisnis berkelanjutan. Melalui program tersebut, para perajin tidak hanya dibantu untuk memudahkan dalam pengadaan bahan baku yang legal dan berkualitas, namun juga mendapatkan berbagai program pelatihan baik aspek produksi, managerial, maupun pemasaran, dan juga diberi akses untuk mengikuti berbagai pameran dalam dan luar negeri dengan disponsori oleh perusahaan dan pemerintah. Diharapkan dengan program tersebut, perajin mampu meningkatkan kualitas produknya, sekaligus meningkatkan nilai penjualan baik dari peningkatan volume penjualan maupun dari peningkatan harga dari para konsumen yang sadar untuk memberikan harga lebih tinggi untuk produk yang bertanggung jawab.

\section{KESIMPULAN}

Dari berbagai kendala dan peluang tersebut, dapat disimpulkan bahwa terdapat peluang sekaligus tantangan yang besar bagi kita dalam mewujudkan industri perhiasan emas dan perak yang bertanggung jawab dan berkelanjutan. Di satu sisi, para pelaku usaha perhiasan emas dan perak dapat memanfaatkan peluang dan tantangan ini untuk meningkatkan bisnisnya, di mana emas dan perak yang dihasilkan melalui kegiatan penambangan, pengolahan dan pemurnian, serta proses pembuatan perhiasan sesuai prinsip keadilan lingkungan, keadilan sosial dan selalu memperhatikan aspek keberlanjutan akan dinilai semakin tinggi oleh konsumen karena memiliki nilai intrinsik lebih dari sekedar keindahan fisiknya.

Dengan penegakkan aturan hukum, edukasi kepada konsumen, dan kolaborasi antara penambang, perajin, dan pedagang perhiasan perak dan emas yang dipandu oleh konsep Strategic CSR, khususnya CSV, akan terbentuk rantai pasokan dan rantai pasar yang mendukung terciptanya industri perhiasan emas dan perak yang berkelanjutan karena selain keuntungan finansial yang meningkat, tanggung jawab sosial dan lingkungan juga dapat terpenuhi. Kasus kerjasama antara 
ANTAM dengan para perajin perhiasan di Celuk, Bali, membuktikan bahwa CSV memang bisa diwujudkan dalam industry tambang.

\section{DAFTAR PUSTAKA}

Albanese, T. 2014. Creating Shared Value through Mining in Africa. The Mining on Top: Africa, London Summit, June.

Baines, P. 2015. Doing Good by Doing Good. Why Creating Shared Value is the Key to Powering Business Growth and Innovation. Wiley.

Crane, A., Palazzo, G., Spence, L., and Matten, D. 2014. Contesting the Value of "Creating Shared Value”. California Management Review Vol. 56/2.

Elkington, J. 1997. Cannibals with Forks: The Triple Bottom Line of $21^{\text {st }}$ Century Business. Capstone.

Hennigs, N., Wiedmann, K., Klarmann, C., and Behrens, S. 2013. Sustainability as Part of the Luxury Essence: Delivering Value through Social and Environmental Excellence. Greenleaf Publishing.

Michelini, L. 2012. Social Innovation and New Business Models: Creating Shared Value in Lowincome Markets. Springer.

Porter, M and Kramer, M. 2011. Creating Shared Value: How to Reinvent Capitalism-and Unleash a Wave of Innovation and Growth. Harvard Business Review January-February.

Porter, M and Kramer, M. 2006. Strategy and Society: The Link between Competitive Advantage and Corporate Social Responsibility. Harvard Business Review, December.

Porter, M. and Kramer, M. 2002. The Competitive Advantage of Corporate Philantrophy, Harvard Business Review, December.

Prahalad, C. K. 2006. The Fortune at the Bottom of the Pyramid. Wharton School Publishing.

Ragas, M. and Culp, R. 2014. Business Essentials for Strategic Communicators: Creating Shared Value for Organization and Its Stakeholders. Palgrave Macmillan.

Sirsly, C. and Lamertz, K. 2008. When does a Corporate Social Responsibility Initiative Provide a First-Mover Advantage? Business \& Society, Vol. 47/3.

Welford, R. 2013. Creating Shared Value. Presentation in A+ CSR Indonesia CEO Breakfast, 14 November.

Werther, W. and Chandler, D. 2011. Strategic Corporate Social Responsibility: Stakeholders in Global Environment. Sage Publications.

Wieland, J. (ed.). 2017. Creating Shared Value-Concepts, Experience, Criticism. Springer. 